\title{
Preclinical pharmacology, efficacy, and safety of varenicline in smoking cessation and clinical utility in high risk patients
}

This article was published in the following Dove Press journal:

Drug, Healthcare and Patient Safety

II April 2010

Number of times this article has been viewed

\section{Zheng-Xiong Xi}

National Institute on Drug Abuse, Intramural Research Program, Baltimore, MD, USA
Correspondence: Zheng-Xiong Xi National Institute on Drug Abuse, Intramural Research Program,

Baltimore, MD 21224, USA

Tel +I 4437402517

Fax + I 443740 278 I

Email zxi@intra.nida.nih.gov
Abstract: Smoking is still the most prominent cause of preventable premature death in the United States and an increasing cause of morbidity and mortality throughout the world. Although the current treatments such as nicotine replacement therapy (NRT) and bupropion are effective, long-term abstinence rates are low. Mechanism studies suggest that the pleasurable effects of smoking are mediated predominantly by nicotine, which activates the brain reward system by activation of brain $\alpha 4 \beta 2$ nicotinic acetylcholine receptors (nAChRs). Varenicline is a novel $\alpha 4 \beta 2 \mathrm{nAChR}$ partial agonist and has been found to be even more effective than NRT or bupropion in attenuating smoking satisfaction and in relieving craving and withdrawal symptoms after abstinence. Thus, varenicline has been recently approved to be a first-line medication for smoking cessation in the United States and European countries. Varenicline is generally well tolerated in healthy adult smokers, with the most commonly reported adverse effects being nausea, insomnia, and headache. However, growing postmarketing data has linked varenicline to an increase in neuropsychiatric symptoms such as seizures, suicidal attempts, depression, and psychosis as well as serious injuries potentially relating to unconsciousness, dizziness, visual disturbances, or movement disorders. Therefore, new safety warnings are issued to certain high risk populations, such as patients with mental illness and operators of commercial vehicles and heavy machinery. In particular, pilots, air traffic controllers, truck and bus drivers have been banned from taking varenicline.

Keywords: nicotine, varenicline, $\alpha 4 \beta 2$ nicotinic acetylcholine receptor, nAChRs, partial agonist, smoking cessation

\section{Introduction}

It is estimated that about 1.3 billion people smoke cigarettes worldwide and about 500 million people die annually from tobacco-related diseases. ${ }^{1-3}$ In the United States (US), about 45 million adults ( 20\%) smoke cigarettes or are exposed to secondhand smoking, resulting in about $18 \%$ of total mortality and 440,000 annual premature deaths. ${ }^{1,2}$ The annual economic cost of smoking in the US is about 200 billion dollars. Smoking cessation has shown to significantly reduce the risk of many smoking-related diseases such as lung cancer, chronic lung diseases, myocardial infarction, and stroke as well as decrease morbidity and mortality related to tobacco use. ${ }^{3}$

However, tobacco dependence is a chronic relapse disorder that is difficult to treat. ${ }^{3}$ Despite the availability of effective pharmacologic aids, such as nicotine replacement therapy (NRT) and bupropion sustained-release, these treatments only help 5\%-15\% of people to maintain long-term abstinence from smoking. ${ }^{4-6}$ Craving and withdrawal symptoms after tobacco cessation are the most important reasons to prevent smokers 
from achieving long-term tobacco abstinence. For these reasons, novel pharmacotherapies are being developed in an attempt to improve long-term abstinence outcomes. Among the most promising of treatments is varenicline, a novel partial $\alpha_{4} \beta_{2}$ nicotinic acctylcholine receptors (nAChR) agonist, which has recently been approved by the US Food and Drug Administration (FDA) as a smoking cessation aid. Varenicline has been found to be even more effective than placebo, NRT or bupropion in clinical trials. ${ }^{5,6}$ In this article, we review the mechanism-based medication development strategies, preclinical pharmacology, efficacy, and safety profiles of varenicline in the treatment of cigarette smoking in humans.

\section{Mechanism of tobacco dependence}

The mechanisms underlying tobacco addiction are not completely understood. Accumulating evidence indicates that nicotine is the major addictive component in tobacco. ${ }^{7}$ Nicotine binds to central and peripheral nAChRs. Acetylcholine (Ach) is an endogenous neurotransmitter that binds to and activates both $\mathrm{nAChRs}$ and muscarinic acetylcholine receptors. Neuronal nAChRs are ligand-gated ion channels with high permeability to $\mathrm{Ca}^{++}$, and are formed from combinations of five subunits. ${ }^{8,9}$ To date, twelve different neuronal nAChR subunits have been cloned, including nine $\alpha$-subunits $(\alpha 2-\alpha 10)$ and three $\beta$-subunits $(\beta 2-\beta 4)$. Non-neuronal subunits, $\alpha 1, \beta 1, \gamma, \delta$, and $\varepsilon$, form peripheral nicotinic receptors at the neuromuscular junction. ${ }^{10}$ The neuronal subunits combine with two $\alpha$ - and three $\beta$-, or five $\alpha 7$-subunits to form nAChRs (Figure 1). ${ }^{10,11}$ Both the $\alpha 4 \beta 2$ and $\alpha 7$ subtypes of nAChRs are the most abundant subtypes in the brain and are localized on presynaptic terminals, somatodendrites, and postsynaptic cells. ${ }^{8,9}$ Activation of presynaptic nAChRs by $\mathrm{ACh}$ or nicotine potentiates neurotransmitter release, while activation of postsynaptic nAChRs increases excitability of postsynaptic cells by increasing influx of $\mathrm{Na}^{+}$and $\mathrm{Ca}^{++}$via nAChR channels. ${ }^{10-12}$

One third of the $\alpha 4 \beta 2 \mathrm{nAChRs}$ are located on the dopamine (DA) cells in the mesolimbic DA system (Figure 1). ${ }^{13,14}$ This system originates from DA neurons in the ventral tegmental area (VTA) in the midbrain and projects to the forebrain nucleus accumbens (NAc) and the prefrontal cortex (PFC). ${ }^{15}$ The $\alpha 4 \beta 2$ nAChR subtype has been thought to play a vital role in mediating nicotine reward. ${ }^{8-10}$ This is supported by the finding that blockade of $\alpha 4 \beta 2$ nAChRs by dihydro- $\beta$-erythroidine (DH $\beta E$ ) inhibits nicotine self-administration in rats. ${ }^{16}$ Genetic deletion of $\alpha 4$ or $\beta 2$ subunits largely abolishes nicotine binding to mouse brain and inhibits nicotine self-administration and nicotine-induced increases in NAc DA. ${ }^{17,18}$ Similarly, nicotine-mediated currents from VTA (DA) neurons are also inhibited by $\mathrm{DH} \beta \mathrm{E}^{17,19}$ or dramatically decreased on midbrain neurons in $\beta 2$-kockout mice. ${ }^{17,19,20}$ These data suggest that both the behavioral and DA-releasing effects of nicotine are

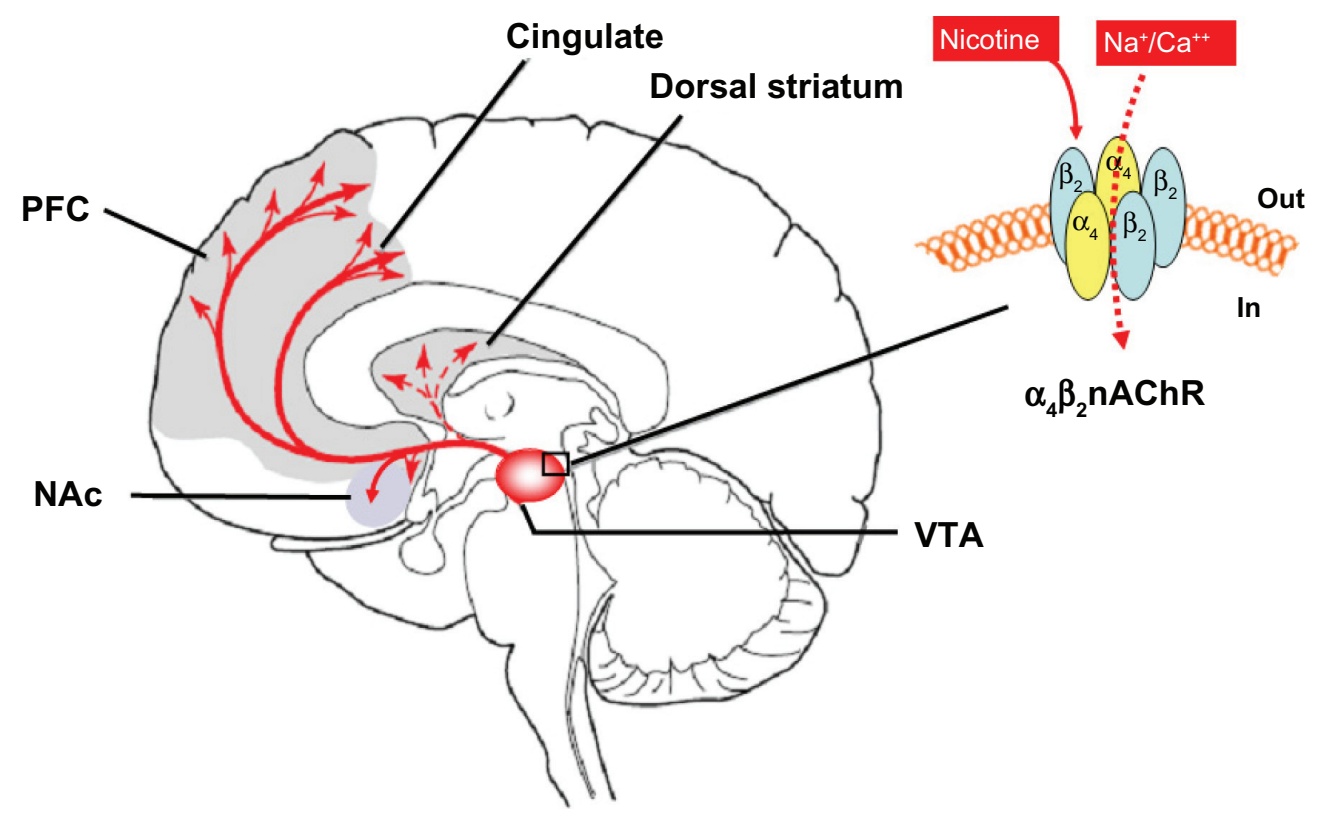

Figure I Schematic diagram of the mesolimbic DA projection pathway in human brain, illustrating that nicotine activates $\alpha 4 \beta 2 \mathrm{nAChRs}$ located on DA neurons in the VTA and increases VTA DA neuron activity as well as DA release in the NAc, dorsal striatum, and PFC. Insert: Simplified structure of $\alpha 4 \beta 2 \mathrm{nAChR}$ (ion channel) located on surface of VTA DA neurons. Activation of $\alpha 4 \beta 2 \mathrm{nAChR}$ opens the receptor ion channel, causing influx of $\mathrm{Na}^{+}$and/or Ca ${ }^{++}$and depolarization of VTA DA neuron. Abbreviations: DA, dopamine; NAc, nucleus accumbens; nAChR, nicotinic acetylcholine receptors; PFC, prefrontal cortex; VTA, ventral tegmental area. 
mediated predominantly by activation of $\alpha 4 \beta 2 \mathrm{nAChRs}$ in the mesolimbic DA system. ${ }^{8,9,17,21}$ As stated above, the $\alpha 4 \beta 2$ $\mathrm{nAChR}$ is a receptor ion channel with high affinity to nicotine. High concentrations of nicotine binds to the $\alpha 4 \beta 2$ receptor, causing the ion channel opening and $\mathrm{Na}^{+}$influx, which subsequently depolarizes VTA DA neurons and increases DA release in the NAc (Figure 1). ${ }^{21}$

\section{Medication strategies for the treatment of nicotine addiction}

Modulating nAChRs can be achieved using nAChR agonists, antagonists, or partial agonists. Full agonists, such as NRT, mimic the effects of nicotine by activating the receptor, therefore reducing withdrawal symptoms during nicotine abstinence. ${ }^{22} \mathrm{NRT}$ is proven effective in smoking cessation, ${ }^{23}$ although it does not produce complete abstinence because the smoker is still physically dependent on the effects of smoking. Antagonists, such as mecamylamine, compete with nicotine or ACh for occupancy of the receptors..$^{24}$ Therefore, a full antagonist may fully block the pharmacological action of nicotine, such as nicotine reward. However, antagonists are prone to induce withdrawal symptoms by themselves. ${ }^{22}$ Surprisingly, mecamylamine in combination with NRT is more effective than NRT alone or mecamylamine alone in smoking cessation. ${ }^{25,26}$ This could be due to a functional effect of the agonist NRT (reduction of the withdrawal syndromes) in combination with the effect of the antagonist mecamylamine (attenuation of the reinforcing effects of nicotine). This finding suggests that the development of a nicotine partial agonist such as cytisine and varenicline may be optimal in the treatment of nicotine dependence because partial agonists display the properties of both agonists and antagonists. Partial agonists occupy the receptors, but only partially activate them. As a consequence, the action of a partial agonist is dependent on the receptor occupancy. ${ }^{27}$ In cigarette smokers, a partial agonist would mostly work as an antagonist during smoking (ie, high nicotine occupancy), but as an agonist during abstinence or withdrawal (ie, low nicotine occupancy). Thus, the rewarding effects of smoking would decrease substantially but not disappear completely, whereas withdrawal symptoms and craving episodes would occur less frequently during drug abstinence due to the release of a low-to-moderate level of DA produced by a partial agonist itself. ${ }^{28-30}$

\section{Cytisine - an unnoticed smoking cessation drug since the 1960 s}

Cytisine has a molecular structure somewhat similar to that of nicotine and varenicline (Figure 2). Cytisine is a natural insecticide present in plants called Cytisus laburnum (Golfen Rain). ${ }^{28}$ Cytisine (Tabex ${ }^{\circledR}$; Sopharma, Sofia, Bulgaria) has been used in Bulgaria, Germany, Poland, and Russia as a smoking cessation aid since the 1960s. ${ }^{29-32}$ Despite its widespread use in Eastern and Central Europe, cytisine has remained largely unnoticed elsewhere, possibly due to limited access to the non-English literature..$^{32}$ In addition, the underlying mechanisms have remained unclear until the 1990s when it was reported that cytisine is a partial agonist of nAChRs with high affinity for $\alpha 4 \beta 2$ receptors. ${ }^{28,33}$ Behavioral studies in experimental animals suggest that cytisine produces low-to-moderate behavioral activation, ${ }^{34,35}$ conditioned place preference, ${ }^{36}$ and drug discriminative effects. ${ }^{37}$ In addition, drug-naive mice also self-administer cytisine intravenously, suggesting that cytisine has certain reinforcing effects. ${ }^{38}$

\section{Preclinical pharmacology of varenicline}

Varenicline as a smoke-cessation aid was developed by Pfizer in 1997, largely based on cytisine described above. ${ }^{39,40}$

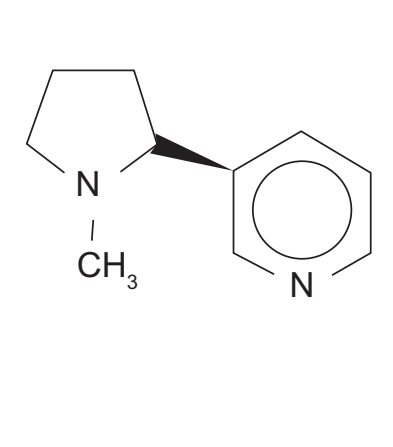

Nicotine

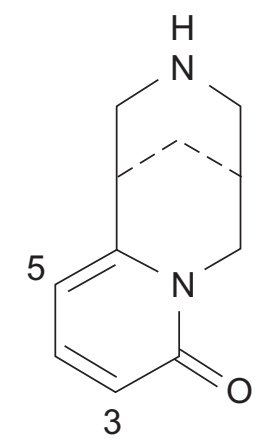

(-)-Cytisine

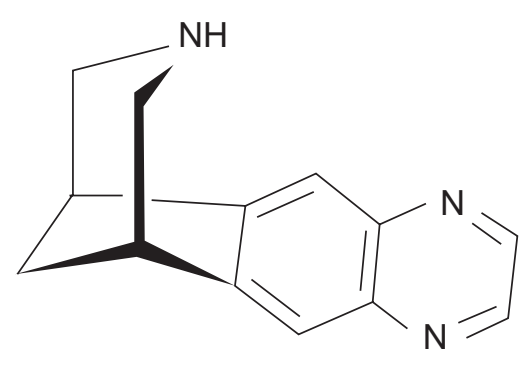

Varenicline

Figure 2 Chemical structures of nicotine, cytisine, and varenicline. 
In vitro binding assays indicate that varenicline has higher binding affinity $\left(\mathrm{K}_{\mathrm{i}}=0.15 \mathrm{nM}\right)$ to $\alpha 4 \beta 2 \mathrm{nAChRs}$ than cytisine $\left(\mathrm{K}_{\mathrm{i}}=0.23 \mathrm{nM}\right)$ or nicotine $\left(\mathrm{K}_{\mathrm{i}}=1.6 \mathrm{nM}\right)$. It has 500-20,000-fold selectivity for $\alpha 4 \beta 2$ receptors over other nAChR subtypes (Table 1). ${ }^{39-41}$ In vitro functional patch clamp studies in HEK cells expressing nAChRs show that varenicline is a partial agonist with $45 \%$ of nicotine's maximal efficacy at $\alpha 4 \beta 2$ nAChRs. ${ }^{39}$ In neurochemical models varenicline has significantly lowered (40\%-60\%) efficacy than nicotine in stimulating $\left[{ }^{3} \mathrm{H}\right]-\mathrm{DA}$ release from rat brain slices in vitro, and in increasing DA release from rat NAc in vivo. ${ }^{39}$ When combined with nicotine, varenicline effectively attenuates the nicotine-induced DA release, consistent with partial agonism. ${ }^{39}$

In animal models of addiction (Table 2), varenicline significantly inhibits nicotine self-administration, ${ }^{39}$ nicotineenhanced brain stimulation reward, ${ }^{42}$ and nicotine priming, but not nicotine-associated cue-induced reinstatement of drug-seeking behavior. ${ }^{43}$ Varenicline itself does not induce reinstatement of nicotine seeking when administered as a priming injection. ${ }^{43}$ Varenicline partially substitutes for nicotine in self-administration testing in animals and partially generalizes to nicotine in the drug discrimination preclinical animal paradigm, ${ }^{39,44}$ suggesting that it may have some abuse potential, but lower than that of nicotine. In addition, varenicline also enhanced the basal locomotor activity in drug-naive rats by itself, while pretreatment with varenicline attenuated acute nicotine-induced hyperlocomotion and repeated nicotine-induced behavioral sensitization. ${ }^{45}$

In addition to being an $\alpha 4 \beta 2 \mathrm{nAChR}$ partial agonist, varenicline is also a full $\alpha 7 \mathrm{nAChR}$ agonist. ${ }^{46}$ To determine which receptor subtype underlies the action of varenicline, we have recently investigated the effects of $\alpha 4 \beta 2$ or $\alpha 7$ receptor agonists or antagonists on varenicline-enhanced electrical brain-stimulation reward (BSR). We found that systemic administration of nicotine or varenicline produced significant BSR enhancement, while pretreatment with varenicline dose-dependently attenuated nicotineenhanced BSR. The BSR-enhancing effect produced by varenicline was blocked by mecamylamine (a full nAChR antagonist) and $\mathrm{DH} \beta \mathrm{E}$ (a selective $\alpha 4$-containing $\mathrm{nAChR}$ antagonist), but not by methyllycaconitine (a selective $\alpha 7 \mathrm{nAChR}$ antagonist), suggesting an effect mediated by activation of $\alpha 4 \beta 2$ receptors. ${ }^{42}$ This suggestion is further supported by findings that SIB-1765F, another selective $\alpha 4 \beta 2 \mathrm{nAChR}$ agonist, produced a dose-dependent enhancement of BSR, while pretreatment with SIB-1765F also attenuated nicotine-enhanced BSR. In contrast, the selective $\alpha 7$ receptor agonist, ARR-17779, altered neither BSR itself nor nicotine-enhanced BSR, at any dose tested. ${ }^{42}$ These findings are consistent with other reports that neither deletion of $\alpha 7$ receptors nor pharmacological blockade of $\alpha 7$ receptors alters the nicotine-produced discriminative stimulus effect. ${ }^{47-49}$ Together, these data suggest that the pharmacotherapeutic effects of varenicline on nicotine's action are mediated by activation of the $\alpha 4 \beta 2$, rather than the $\alpha 7$ nAChR subtype.

The bioavailability of varenicline is high and is unaffected by the time of dosing or administration with food. ${ }^{50}$ After serial measurements, varenicline followed first-order kinetics, with an elimination $\mathrm{T}_{1 / 2}$ of $\sim 24 \mathrm{~h}$ after single and multiple doses. ${ }^{50,51}$ Steady-state levels were achieved within four days with repeated oral dosing. ${ }^{51}$ Pharmacokinetic assays in healthy adult smokers indicated that varenicline did not undergo significant hepatic metabolism. Varenicline is $<20 \%$ plasma protein bound. Its clearance is predominantly renal, with $>90 \%$ excreted unchanged in the urine. Elimination of varenicline by the kidney primarily involves glomerular filtration and active tubular secretion via the renal organic cation transporter hOCT2..$^{51,52}$

\section{Therapeutic efficacy in humans}

Following promising results in preclinical studies, together with a strong theoretical foundation for its use, testing of varenicline began in clinical safety and efficacy trials. Table 3 summarizes the results of the ten clinical trials with varenicline since it was approved by the US FDA in 2006. These trials were conducted in Australia, Canada, Europe, Japan, South Korea, China, Thailand, Singapore, and the US, and enrolled both male and female subjects

Table I In vitro binding affinity and functional activity of nicotine, cytisine, and varenicline at human brain $\mathrm{nAChRs^{28,29,4I }}$

\begin{tabular}{|c|c|c|c|c|c|}
\hline & $\alpha 4 \beta 2^{a}\left(K_{i}, n M\right)$ & $\alpha 3 \beta 4^{\mathrm{b}}\left(\mathrm{K}_{\mathrm{i}}, \mathrm{nM},\right)$ & $\alpha 7^{c}\left(K_{i}, n M\right)$ & $\alpha|\beta| \gamma \delta^{d}\left(K_{i}, n M\right)$ & $\begin{array}{l}\text { Functional activity } \\
\text { at } \alpha 4 \beta 2^{\mathrm{e}}\end{array}$ \\
\hline Nicotine & 1.6 & 530 & 6,300 & 6,300 & - \\
\hline Cytisine & 0.23 & 840 & 4,200 & 250 & $56 \%$ \\
\hline Varenicline & 0.15 & 83.2 & 616.6 & $3,388.4$ & $45 \%$ \\
\hline
\end{tabular}

Notes: ${ }^{a}\left[{ }^{3} \mathrm{H}\right]-$ Nicotine, ${ }^{b}\left[{ }^{3} \mathrm{H}\right]$-Epibatidine, ${ }^{\mathrm{C}}\left[{ }^{125} \mathrm{I}\right]-\alpha$-Bungarotoxin, ${ }^{\mathrm{d}}\left[{ }^{125} \mathrm{I}\right]-\alpha-$-Bungarotoxin, ${ }^{\mathrm{e}} \%$ Response of $\mathrm{I} 0 \mu \mathrm{M}$ cytisine or varenicline relative to $\mathrm{I} 0 \mu \mathrm{M}(-)$-nicotine. 
Table 2 Behavioral effects of cytisine and varenicline in animal models related nicotine addiction

\begin{tabular}{|c|c|c|}
\hline Animal models & Cytisine & Varenicline \\
\hline Locomotor behavior & $\begin{array}{l}\uparrow \text { Locomotion } \\
\text { by itself }{ }^{34,35}\end{array}$ & $\begin{array}{l}\uparrow \text { Locomotion by itself } f^{45} \\
\downarrow \text { Nicotine-induced hyperactivity }{ }^{45} \\
\downarrow \text { Nicotine-induced sensitization }{ }^{45}\end{array}$ \\
\hline $\begin{array}{l}\text { Self-administration } \\
\text { (SA) }\end{array}$ & $\begin{array}{l}\text { Naïve mice self- } \\
\text { administer cytisine }{ }^{38}\end{array}$ & $\begin{array}{l}\downarrow \text { Nicotine } \text { SA }^{39} \\
\text { No effect on food taking }{ }^{39} \\
\text { Supports low SA by itself }{ }^{39,43}\end{array}$ \\
\hline Brain-stimulation reward (BSR) & - & $\begin{array}{l}\uparrow \text { BSR by itself }{ }^{42} \\
\downarrow \text { Nicotine-enhanced BSR }{ }^{42}\end{array}$ \\
\hline Reinstatement & - & $\begin{array}{l}\downarrow \text { Nicotine-induced reinstatement }{ }^{43} \\
\text { But not on cue-induced reinstatement }{ }^{43} \\
\text { No reinstatement by itself } f^{43}\end{array}$ \\
\hline Condition place preference (CPP) & $\begin{array}{l}\text { Intra-VTA cytisine } \\
\text { produces CPP }{ }^{36}\end{array}$ & - \\
\hline Drug discrimination (DD) & $\begin{array}{l}\text { Producing DD by itself } \\
\text { Partially substitutes nicotine in } D D^{37}\end{array}$ & Fully substitutes nicotine in $\mathrm{DD}^{39}$ \\
\hline $\begin{array}{l}\text { Dopamine (DA) in the } \\
\text { nucleus accumbens }\end{array}$ & - & $\begin{array}{l}\uparrow \mathrm{DA} \text { by itself }{ }^{39} \\
\downarrow \text { Nicotine-enhanced DA }{ }^{39}\end{array}$ \\
\hline
\end{tabular}

(age range, 18-75 years) with no major comorbidities in the past year. The primary end point in most of the studies was efficacy, which was assessed primarily in terms of the continuous abstinence rate (CAR) or continuous quit rate $(\mathrm{CQR})$ based on subjective reporting and confirmation by exhaled carbon monoxide (CO) measurement ( $\leq 10 \mathrm{ppm})$. The second end points included the urge to smoke, withdrawal symptoms, and the reinforcing effects of nicotine. In addition, odds ratio (OR) meta-analysis was also used to measure the comparative efficacy and abstinence rates for various smoking cessation medications in some of those clinical trials.

One of the trials reported follow-up data to 24 weeks, ${ }^{53}$ and the others reported data to 52 weeks. ${ }^{54-62}$ During treatment with oral varenicline titrated to $1 \mathrm{mg}$ twice per day (bid), CO-confirmed CQRs or CARs at week 12 ranged from $28.8 \%$ to $65.4 \%$, at week- 24 from $20.8 \%$ to $70.5 \%$, and at week-52 from $14.4 \%$ to $43.6 \%$. In all these trials, varenicline $1 \mathrm{mg}$ bid was associated with significantly higher CARs or CQRs compared with placebo at either week 12, week 24, or week 52 when compared with placebo. Three trials reported significantly higher CARs or CQRs with varenicline $1 \mathrm{mg}$ bid compared to bupropion, ${ }^{55,57,58}$ and one trial reported significantly higher CARs with varenicline compared with NRT (Table 3). ${ }^{62}$ In a relapse-prevention study, CARs were significantly improved at 24 weeks with varenicline relative to placebo $(70.5 \%$ vs $49.6 \%){ }^{59}$

Nides et $\mathrm{a}^{63}$ conducted a pooled data analysis from the Phase III trials by Gonzales et $\mathrm{al}^{57}$ and Jorenby et $\mathrm{al}^{58}$ to explore the relative efficacy of varenicline, bupropion, and placebo for smoking cessation. Pooled CARs for weeks 9 through 12 were significantly greater for varenicline compared with bupropion and placebo $(44.0 \%, 29.7 \%$, and $17.7 \%$, respectively; both comparisons $P<0.001$ ).

West et $\mathrm{al}^{64}$ conducted a similar analysis of pooled data from the same two Phase III trials ${ }^{57,58}$ to evaluate the effects of varenicline, bupropion, and placebo on craving and withdrawal symptoms among smokers. They used the Minnesota Nicotine Withdrawal Scale (MNWS) to score craving and withdrawal symptoms in abstinent smokers $(n=612)$ and the Modified Cigarette Evaluation Questionnaire (mCEQ) to score the reinforcing effects of smoking in nonabstinent smokers $(n=1,115)$. They found that among all participants, cravings (urge to smoke) were significantly reduced with varenicline or bupropion compared with placebo (both $P<0.001$ ) and with varenicline compared with bupropion $(P=0.008)$. Overall, varenicline or bupropion significantly inhibited negative withdrawal syndromes (depression, irritability, anxiety, difficulty concentrating, and insomnia) compared with placebo. In addition, they also found that varenicline-treated patients had significantly lower pleasurable effects of smoking compared with those treated with bupropion and placebo, as assessed by mCEQ scores for smoking satisfaction, psychological reward and enjoyment of respiratory tract sensations.

Cahill et $\mathrm{al}^{65}$ conducted a systemic review and metaanalysis of the efficacy and tolerability of varenicline for 
Table 3 Clinical efficacy (CARs) of varenicline in human clinical trials

\begin{tabular}{|c|c|c|c|c|}
\hline & Varenicline dose & $\begin{array}{l}\text { CARs (\%) } \\
\text { (Week I2) }\end{array}$ & $\begin{array}{l}\text { CARs (\%) } \\
\text { (Week 24) }\end{array}$ & $\begin{array}{l}\text { CARs (\%) } \\
\text { (Week 52) }\end{array}$ \\
\hline Nides et a $\left.\right|^{55}$ & Placebo & 10.6 & 7.3 & 4.9 \\
\hline \multirow[t]{5}{*}{$(n=638)$} & $0.3 \mathrm{mg} / \mathrm{d}, 6 \mathrm{wks}$ & 16.7 & 9.5 & 7.9 \\
\hline & $\mathrm{l} \mathrm{mg} / \mathrm{d}, 6$ wks & 15.1 & 9.5 & 5.6 \\
\hline & I mg, bid, 6 wks & $28.8^{* *}$ & $20.8 * *$ & $14.4^{* *}$ \\
\hline & Bupropion: & $19.8 *$ & 10.3 & 6.3 \\
\hline & 150 mg, bid, 6 wks & & & \\
\hline Oncken et $\mathrm{al}^{56}$ & Placebo & 11.6 & - & 3.9 \\
\hline \multirow[t]{4}{*}{$(n=1,210)$} & $\begin{array}{l}0.5 \mathrm{mg} / \mathrm{d}, 12 \mathrm{wks} \\
\text { (Titrated) }\end{array}$ & $40.8^{* * *}$ & - & $\begin{array}{l}\text { Pooled (Titrated } \\
\text { and Nontitrated): }\end{array}$ \\
\hline & $\begin{array}{l}0.5 \text { mg, bid, I } 2 \text { wks } \\
\text { (Nontitrated) }\end{array}$ & $47.3^{* * *}$ & - & $18.5 * * *$ \\
\hline & $\begin{array}{l}\text { I mg, bid, } 12 \text { wks } \\
\text { (Titrated) }\end{array}$ & $54.6 * * *$ & - & $\begin{array}{l}\text { Pooled (Titrated } \\
\text { and Nontitrated): }\end{array}$ \\
\hline & $\begin{array}{l}\text { I mg, bid } \\
\text { (Nontitrated) }\end{array}$ & $44.2^{* * *}$ & - & $22.4 * * *$ \\
\hline Gonzales et $\mathrm{al}^{57}$ & Placebo & 17.7 & 10.5 & 8.4 \\
\hline \multirow[t]{3}{*}{$(n=1,025)$} & I mg, bid, 12 wks & $44.0 * * *$ & $29.5^{* * *}$ & $21.9 * * *$ \\
\hline & Bupropion: & $29.5 * * *$ & $20.7^{* * *}$ & $16.1^{* * *}$ \\
\hline & $150 \mathrm{mg}$, bid & & & \\
\hline Jorenby et $\mathrm{a}^{58}$ & Placebo & 17.6 & 13.2 & 10.3 \\
\hline \multirow[t]{3}{*}{$(n=I, 027)$} & I mg, bid, 12 wks & $43.9 * * *$ & $29.7^{* * *}$ & $23 * * *$ \\
\hline & Bupropion: & $29.8 * * *$ & $20.2^{* *}$ & 14.6 \\
\hline & 150 mg, bid, I 2 wks & & & \\
\hline Tonstad et a $\left.\right|^{59}$ & Placebo & - & 49.6 & 36.9 \\
\hline$(\mathrm{n}=1,210)$ & I mg, bid, I 2 wks & - & $70.5^{* * *}$ & $43.6 *$ \\
\hline Tsai et $\mathrm{al}^{53}$ & Placebo & 32.3 & 21.8 & \\
\hline$(n=250)$ & I mg, bid, I 2 wks & $59.5^{* * *}$ & $46.8^{* * *}$ & \\
\hline Nakamura et $\mathrm{a}^{60}$ & Placebo & 39.5 & 29.5 & 23.3 \\
\hline \multirow[t]{3}{*}{$(n=619)$} & $0.25 \mathrm{mg}$, bid, 12 wks & $54.7^{*}$ & 33.6 & 27.3 \\
\hline & $0.5 \mathrm{mg}$, bid, 12 wks & $55.5^{* *}$ & 35.2 & 28.9 \\
\hline & I mg, bid, I 2 wks & $65.4 * * *$ & 37.7 & 34.6 \\
\hline Niaura et $\mathrm{a}^{61}$ & Placebo & 11.6 & 9 & 7.7 \\
\hline$(n=320)$ & $0.5-2 \mathrm{mg} / \mathrm{d}, 12$ wks & $40.1 * * *$ & $28 * * *$ & $22.3^{* * *}$ \\
\hline Aubin et $\mathrm{a}^{62}$ & NRT, $21 \mathrm{mg} / \mathrm{d}, 6$ wks & 42.2 & 26.6 & 19.8 \\
\hline$(n=757)$ & I mg, bid, 12 wks & $55.6^{\prime \prime \prime m ~}$ & 32.2 & $25.9^{\#}$ \\
\hline Wang et $\mathrm{a}^{67}$ & Placebo & - & 31.6 & 25 \\
\hline$(n=333)$ & I mg, bid, 12 wks & - & $50.3^{* * *}$ & $38.2^{* *}$ \\
\hline
\end{tabular}

Notes: ${ }^{* * * P}<0.05$, ${ }^{* * P}<0.01$, ${ }^{*} P<0.001$, compared to placebo; ${ }^{*} P<0.05$, ${ }^{*} P<0.001$, compared to NRT.

smoking cessation in seven placebo-controlled trials, one relapse-prevention trial, and one open-label trial comparing varenicline with NRT. The nine trials covered 7,267 participants, 4,744 of whom used varenicline. The pooled ORs for CAR for varenicline versus placebo at six months or longer was 2.33 (95\% confidence interval [CI]: 1.95-2.80), for varenicline versus bupropion at one year was 1.52 (95\% CI: 1.22-1.88), and for varenicline versus NRT at one year was 1.31 (95\% CI: 1.01-1.71). These data suggest that varenicline is even more effective than bupropion or NRT.
Mills et $\mathrm{al}^{66}$ conducted large-scale pooled data analysis from nine trials with varenicline $(\mathrm{n}=5,192), 101$ clinical trials with NRT $(\mathrm{n}=31,321)$, and 31 trials with bupropion $(n=11,118)$ in order to compare treatment effects across interventions. They found that the pooled ORs for smoking cessation at four weeks post-target quit data with varenicline, NRT, and bupropion were $3.16,2.25$, and 2.05, respectively ( $P<0.001$, compared to placebo). Two trials evaluated head to head comparisons of varenicline and bupropion, and found a pooled OR $1.86(P<0.001)$. Indirect comparison between 
varenicline and NRT was OR $1.56(P<0.001)$, and between varenicline and bupropion OR $1.40(P=0.01)$.

Taken together, all these clinical data suggest that varenicline is superior to placebo, NRT, and bupropion for achieving abstinence from smoking in the short-term. Varenicline not only significantly attenuates the craving and withdrawal symptoms that occur during abstinence from smoking, but also significantly reduces the rewarding effects of nicotine and delay smoking relapse. Thus, varenicline, as the newest agent approved for smoking cessation, offers a new therapeutic option for the treatment of nicotine addiction.

\section{Tolerability}

Varenicline is generally well tolerated, with the most commonly reported adverse effects being nausea $(28.8 \%$, $9.9 \%$, and $9.1 \%$ ), insomnia $(14.2 \%, 21.5 \%$, and 12.6$)$, and headache $(14.2 \%, 11.1 \%$, and 12.4$)$ when compared to bupropion or placebo. ${ }^{54}$

\section{Nausea}

Mild to moderate nausea was the most frequently reported adverse effect (overall incidence, $24.4 \%-52.0 \%$ ) that occurred at a higher rate in varenicline group than in placebo groups. Most episodes of nausea began in the first week of treatment and lasted for a median duration of $\leq 12$ days. Dose titration appeared to reduce the overall incidence of nausea. ${ }^{56}$ There was a low incidence of nausea $(13.4 \%)$ in vareniclinetreated patients in the self-regulated flexible dosing study. ${ }^{61} \mathrm{In}$ clinical trials, rates of treatment discontinuation due to nausea were generally $<5 \%$ in varenicline-treated patients. ${ }^{54}$

\section{Insomnia}

Insomnia was another commonly reported adverse effect $(14.0 \%-37.2 \%)$ associated with varenicline in the clinical trials. ${ }^{5,54}$ In general, insomnia occurred during the first four weeks of treatment with varenicline and became less common as treatment continued. In one extended treatment study, ${ }^{67}$ the incidence of insomnia was $19.1 \%$ with varenicline and $9.5 \%$ with placebo, suggesting that insomnia may be a common symptom of nicotine withdrawal during smoking-cessation attempts.

\section{Headache}

Other common adverse effects include headache, abnormal dreams, sleep disturbance, dizziness, dry mouth, increased appetite, weight gain, and constipation, which generally occurred at rates twice those with placebo. ${ }^{55-67}$ These adverse events were mild-to-moderate and transient, occurring predominantly during the first four weeks of therapy. The rates of discontinuation of varenicline treatment due to these adverse effects were $<2 \%$ of participants.

\section{Utility in high risk people}

Since the approval of varenicline in May 2006, post-marketing surveillance suggests an association between varenicline and increased risk of erratic behavior, agitation, suicidal attempt, depression, psychosis, and severe injuries. ${ }^{68}$ While some of the behavioral and mood changes may be associated with nicotine withdrawal, some occurred in people who continued smoking while on the medication. The Institute for Safe Medication Practices (ISMP), an independent safety group, analyzed all adverse effects since the approval for marketing and found that varenicline accounted for more reports of serious adverse effects than any other drug in the US. ${ }^{69,70}$ Accordingly, the following people are thought to be high-risk to the use of varenicline.

\section{Patients with mental illnesses}

In the fourth quarter report of $2007,{ }^{71}$ the FDA reported that among the total 988 serious injuries related to varenicline from 2006 to December 2007, there were 227 reports of suicidal attempt or behavior, 397 cases of possible psychosis, and 525 reports of hostility or aggression within days to weeks of initiating varenicline therapy for smoking cessation. Based on these reports, in November 2007, the FDA issued an early alert about the safety of varenicline, emphasizing the need for screening for pre-existing psychiatric illness before using varenicline and the importance of monitoring/reporting of mood or behavior changes. ${ }^{71}$ In May 2008, the FDA updated the previous Public Health Advisory and required that all patients should be observed and report to their physicians immediately for any mood or behavior changes, or worsening of preexisting psychiatric illness, during or upon discontinuation of varenicline therapy. ${ }^{72}$ This safety concern in such high-risk patients was further emphasized in more recent clinical reports. ${ }^{73-76}$ For example, about 5\% patients (from the total 2,682 patients since December 2006) in the UK reported psychiatric effects during treatment with varenicline, including sleep disorder $(43,1.6 \%)$, anxiety $(33,1.2 \%)$, depression $(29,1.0 \%)$, abnormal dreams $(26,1.0 \%)$, mood change $(17,0.6 \%)$, and suicidal events $(n=5) .{ }^{77}$

\section{Commercial vehicle drivers and heavy machinery operators}

In addition to those psychiatric effects described above, in the fourth quarter report of $2007,{ }^{71}$ the FDA also reported 372 
movement disorders, 173 serious accidental injuries (including 28 traffic accidents and 77 falls), at least 148 reports of visual disturbances, 224 reports of potential cardiac rhythm disturbances, 338 moderate to severe skin reactions, and numerous reports of drowsiness that may affect patients' ability to drive or operate machinery. Based on these reports, the ISMP issued immediate safety concerns related to varenicline use among operators of vehicles and heavy machinery as well as in any setting in which alertness and motor control are required to avoid serious injury. In May 2008, the Federal Motor Carrier Safety Administration and Federal Aviation Administration announced that pilots, air-traffic controllers, and truck and bus drivers are barred from taking smokingcessation drug. ${ }^{78,79}$

\section{Conclusions}

Varenicline (Chantix ${ }^{\circledR}$; Pfizer, New York, NY), an $\alpha 4 \beta 2$ nAChR partial agonist, is the first in a new class of agents for smoking cessation. In the updated clinical practice guideline from the US Public Health Service, varenicline is recommended as a well-tolerated and effective first-line treatment option for smoking cessation. We should note that the majority of published clinical trials of the efficacy and tolerability of varenicline have generally excluded smokers with comorbid conditions (ie, psychiatric disorders, cardiovascular diseases), obese patients, adolescents, pregnant women, and light smokers ( $<10$ cigarettes/d), which may reduce the generalization of the results to the broad population of smokers. To date, almost all clinical trials have been sponsored by the manufactures of varenicline, suggesting that potential clinician bias may also affect the results even when double-blind procedures are used. Thus, more clinical-trials and postmarketing data are needed to confirm its efficacy, safety, and tolerability. Given the growing evidence suggesting a possible association between varenicline and increased psychiatric symptoms and other severe injuries potentially relating to unconsciousness, the FDA has issued special warning for the use of varenicline in patients with pre-existing psychiatric illnesses, and the Federal Motor Carrier Safety Administration and Federal Aviation Administration have banned the use of varenicline in pilots, air-traffic controllers, and truck and bus drivers.

\section{Acknowledgments}

This work was supported by the Intramural Research Program of the National Institute on Drug Abuse (NIDA) and National Institutes of Health (NIH), USA.

\section{Disclosure}

The author reports no conflicts of interest in this work.

\section{References}

1. Cigarette smoking among adults, United States 2006. MMWR Morb Mortal Wkly Rep. 2007;56:1157-1161.

2. 2008 PHS Guideline Update Panel, Liaisons, and Staff. Treating tobacco use and dependence: 2008 update US Public Health Service Clinical Practice Guideline executive summary. Respir Care. 2008;53: 1217-1222.

3. Smoking-attributable mortality, years of potential life lost, and productivity losses, United States 2000-2004. Morb Mortal Wkly Rep. 2008;57:1226-1228.

4. Etter JF. Cytisine for smoking cessation: a literature review and a metaanalysis. Arch Intern Med. 2006;166:1553-1559.

5. Hays JT, Ebbert JO, Sood A. Efficacy and safety of varenicline for smoking cessation. Am J Med. 2008;121(4 Suppl 1):S32-S42.

6. Garrison GD, Dugan SE. Varenicline: a first-line treatment option for smoking cessation. Clin Ther. 2009;31:463-491.

7. Goldberg SR, Spealman RD, Goldberg DM. Persistent behavior at high rates maintained by intravenous self-administration of nicotine. Science. 1981;214:573-575.

8. Jones S, Sudweeks S, Yakel JL. Nicotinic receptors in the brain: correlating physiology with function. Trends Neurosci. 1999;22: $555-561$.

9. Dani JA, Biasi MD. Cellular mechanisms of nicotine addiction. Pharmacol Biochem Behav. 2001;70:439-446.

10. Le Novère N, Corringer PJ, Changeux JP. The diversity of subunit composition in nAChRs: evolutionary origins, physiologic, and pharmacologic consequences. J Neurobiol. 2002;53:447-456.

11. McGehee DS, Role LW. Physiological diversity of nicotinic acetylcholine receptors expressed by vertebrate neurons. Annu Rev Physiol. 1995;57:521-546.

12. Wonnacott S. Presynaptic nicotinic ACh receptors. Trends Neurosci. 1997;20:92-98.

13. Clarke PB, Pert A. Autoradiographic evidence for nicotine receptors on nigrostriatal and mesolimbic dopaminergic neurons. Brain Res. 1985;348:355-358.

14. Zhou FM, Wilson C, Dani JA. Muscarinic and nicotinic cholinergic mechanisms in the mesostriatal dopamine systems. Neuroscientist. 2003;9:23-36.

15. Wise RA. Dopamine, learning, and motivation. Nat Rev Neurosci. 2004;5:483-494.

16. Watkins SS, Epping-Jordan MP, Koob GF, et al. Blockade of nicotine self-administration with nicotinic antagonists in rats. Pharmacol Biochem Behav. 1999;62:743-751.

17. Picciotto MR, Zoli M, Rimondini R, et al. Acetylcholine receptors containing the beta 2 subunit are involved in the reinforcing properties of nicotine. Nature. 1998;391:173-177.

18. Marubio LM, Gardier AM, Durier S, et al. Effects of nicotine in the dopaminergic system of mice lacking the alpha4 subunit of neuronal nicotinic acetylcholine receptors. Eur J Neurosci. 2003;17: 1329-1337.

19. Wooltorton JR, Pidoplichko VI, Broide RS, et al. Differential desensitization and distribution of nicotinic acetylcholine receptor subtypes in midbrain dopamine areas. J Neurosci. 2003;23: 3176-3185.

20. Picciotto MR, Zoli M, Léna C, et al. Abnormal avoidance learning in mice lacking functional high-affinity nicotine receptor in the brain. Nature. 1995;374:65-67.

21. Xi ZX, Spiller K, Gardner EL. Mechanism-based medication development for the treatment of nicotine dependence. Acta Pharmacol Sin. 2009;30:723-739.

22. Carrozzi L, Pistelli F, Viegi G. Pharmacotherapy for smoking cessation. Ther Adv Respir Dis. 2008;2:301-317. 
23. Silagy C, Lancaster T, Stead L, et al. Nicotine replacement therapy for smoking cessation. Cochrane Database Syst Rev. 2004;3: CD000146.

24. Lancaster T, Stead LF. Mecamylamine (a nicotine antagonist) for smoking cessation. Cochrane Database Syst Rev. 2000;2:CD001009.

25. Rose JE, Levin ED. Concurrent agonist-antagonist administration for the analysis and treatment of drug dependence. Pharmacol Biochem Behav. 1992;41:219-226.

26. Rose JE, Behm FM, Westman EC, et al. Mecamylamine combined with nicotine skin patch facilitates smoking cessation beyond nicotine patch treatment alone. Clin Pharmacol Ther. 1994;56:86-99.

27. Childress AR, O'Brien CP. Dopamine receptor partial agonists could address the duality of cocaine craving. Trends Pharmacol Sci. 2000;21:6-9.

28. Coe JW, Brooks PR, Wirtz MC, et al. 3, 5-Bicyclic aryl piperidines: a novel class of alpha4beta2 neuronal nicotinic receptor partial agonists for smoking cessation. Bioorg Med Chem Lett. 2005;15: 4889-4897.

29. Barlow RB, McLeod LJ. Some studies on cytisine and its methylated derivatives. Br J Pharmacol. 1969;35:161-174.

30. Benndorf S, Scharfenberg G, Kempe G, et al. Smoking withdrawal treatment with Cytisine (Tabex). Results of a semi-annual survey of former smokers after 4 weeks of therapy. Dtsch Gesundheitsw. 1970;24:774-776.

31. Scharfenberg G, Benndorf S, Kempe G. Cytisine (Tabex) as a pharmaceutical aid in stopping smoking. Dtsch Gesundheitsw. 1971;26:463-465.

32. Etter JF, Lukas RJ, Benowitz NL, et al. Cytisine for smoking cessation: a research agenda. Drug Alcohol Depend. 2008;92:3-8.

33. Papke RL, Heinemann SF. Partial agonist properties of cytisine on neuronal nicotinic receptors containing the $\beta 2$ subunit. Mol Pharmacol. 1994;45:142-149.

34. Stolerman IP, Garcha HS, Mirza NR. Dissociations between the locomotor stimulant and depressant effects of nicotinic agonists in rats Psychopharmacology (Berl). 1995;117:430-437.

35. Reavill C, Walther B, Stolerman IP, et al. Behavioral and pharmacokinetic studies on nicotine, cytisine, and lobeline. Neuropharmacology. 1990;29:619-624.

36. Museo E, Wise RA. Place preference conditioning with ventral tegmental injections of cytisine. Life Sci. 1994;55:1179-1186.

37. Chandler CJ, Stolerman IP. Discriminative stimulus properties of the nicotinic agonist cytisine. Psychopharmacology (Berl). 1997;129:257-264.

38. Rasmussen T, Swedberg MD. Reinforcing effects of nicotinic compounds: intravenous self-administration in drug-naive mice. Pharmacol Biochem Behav. 1998;60:567-573.

39. Rollema H, Chambers LK, Coe JW, et al. Pharmacological profile of the alpha4beta2 nicotinic acetylcholine receptor partial agonist varenicline, an effective smoking cessation aid. Neuropharmacology 2007;52:985-994.

40. Rollema H, Coe JW, Chambers LK, et al. Rationale, pharmacology, and clinical efficacy of partial agonists of alpha4beta $2 \mathrm{nACh}$ receptors for smoking cessation. Trends Pharmacol Sci. 2007;28:316-325.

41. Carroll FI, Yokota Y, Ma W, et al. Synthesis, nicotinic acetylcholine receptor binding, and pharmacological properties of 3'-(substituted phenyl) deschloroepibatidine analogs. Bioorg Med Chem. 2008;16:746-754.

42. Spiller K, Xi ZX, Li X, et al. Varenicline attenuates nicotine-enhanced brain-stimulation reward by activation of alpha4beta 2 nicotinic receptors in rats. Neuropharmacology. 2009;57:60-66.

43. O'Connor EC, Parker D, Rollema H, et al. The alpha4beta2 nicotinic acetylcholine-receptor partial agonist varenicline inhibits both nicotine self-administration following repeated dosing and reinstatement of nicotine seeking in rats. Psychopharmacology. 2009;Dec 5. [Epub ahead of print]

44. Smith JW, Mogg A, Tafi E, et al. Ligands selective for alpha4beta2 but not alpha3beta4 or alpha7 nicotinic receptors generalize to the nicotine discriminative stimulus in the rat. Psychopharmacology. 2007;190:157-170.
45. Zaniewska M, McCreary AC, Stefański R, et al. Effect of varenicline on the acute and repeated locomotor responses to nicotine in rats. Synapse. 2008;62:935-939.

46. Mihalak KB, Carroll FI, Luetje CW. Varenicline is a partial agonist at alpha4beta2 and a full agonist at alpha7 neuronal nicotinic receptors. Mol Pharmacol. 2006;70:801-805.

47. Brioni JD, Kim DJB, O'Neill AB. Nicotine cue: lack of effect of the alpha7 nicotinic receptor antagonist methyllycaconitine. Eur $J$ Pharmacol. 1996;301:1-5.

48. Gommans J, Stolerman IP, Shoaib M. Antagonism of the discriminative and aversive stimulus properties of nicotine in $\mathrm{C} 57 \mathrm{BL} / 6 \mathrm{~J}$ mice. Neuropharmacology. 2000;39:2840-2847.

49. Stolerman IP, Chamberlain S, Bizarro L, et al. The role of nicotinic receptor alpha7 subunits in nicotine discrimination. Neuropharmacology. 2004;46:363-371.

50. Faessel HM, Smith BJ, Gibbs MA, et al. Single-dose pharmacokinetics of varenicline, a selective nicotinic receptor partial agonist, in healthy smokers and nonsmokers. J Clin Pharmacol. 2006;46: 991-998.

51. Faessel HM, Gibbs MA, Clark DJ, et al. Multiple-dose pharmacokinetics of the selective nicotine receptor partial agonist, varenicline, in healthy smokers. J Clin Pharmacol. 2006;46:1439-1448.

52. Feng B, Obach RS, Burstein AH, et al. Effect of human renal cationic transporter inhibition on the pharmacokinetics of varenicline, a new therapy for smoking cessation: An in vitro-in vivo study. Clin Pharmacol Ther. 2008;83:567-576.

53. Tsai ST, Cho HJ and Cheng HS, et al. A randomized, placebo-controlled trial of varenicline, a selective alpha4beta 2 nicotinic acetylcholine receptor partial agonist, as a new therapy for smoking cessation in Asian smokers. Clin Ther. 2007;29:1027-1039.

54. Garrison GD, Dugan SE. Varenicline: a first-line treatment option for smoking cessation. Clin Ther. 2009;31:463-491.

55. Nides M, Oncken C and Gonzales D, et al. Smoking cessation with varenicline, a selective alpha4beta2 nicotinic receptor partial agonist: results from a 7-week, randomized, placebo-, and bupropion-controlled trial with 1-yearfollow-up.ArchInternMed.2006;166: 1561-1568.

56. Oncken C, Gonzales D and Nides M, et al. Efficacy and safety of the novel selective nicotinic acetylcholine receptor partial agonist, varenicline, for smoking cessation. Arch Intern Med. 2006;166: 1571-1577.

57. Gonzales D, Rennard SI, Nides M, et al. Varenicline, an alpha4beta2 nicotinic acetylcholine receptor partial agonist, vs sustained-release bupropion and placebo for smoking cessation: a randomized controlled trial. JAMA. 2006;296:47-55.

58. Jorenby DE, Hays JT, Rigotti NA, et al. Efficacy of varenicline, an alpha4beta2 nicotinic acetylcholine receptor partial agonist, vs placebo or sustained-release bupropion for smoking cessation: a randomized controlled trial. JAMA. 2006;296:56-63.

59. Tonstad S, Tønnesen P, Hajek P, et al. Effect of maintenance therapy with varenicline on smoking cessation: a randomized controlled trial. JAMA. 2006;296:64-71.

60. Nakamura M, Oshima A, Fujimoto Y, et al. Efficacy and tolerability of varenicline, an alpha4beta 2 nicotinic acetylcholine receptor partial agonist, in a 12-week, randomized, placebo-controlled, dose-response study with 40-week follow-up for smoking cessation in Japanese smokers. Clin Ther. 2007;29:1040-1056.

61. Niaura R, Hays JT, Jorenby DE, et al. The efficacy and safety of varenicline for smoking cessation using a flexible dosing strategy in adult smokers: a randomized controlled trial. Curr Med Res Opin. 2008;24:1931-1941.

62. Aubin HJ, Bobak A, Britton JR, et al. Varenicline versus transdermal nicotine patch for smoking cessation: results from a randomized openlabel trial. Thorax. 2008;63:717-724.

63. Nides M, Glover ED, Reus VI, et al. Varenicline versus bupropion SR or placebo for smoking cessation: a pooled analysis. Am J Health Behav. 2008;32:664-675. 
64. West R, Baker CL, Cappelleri JC, et al. Effect of varenicline and bupropion SR on craving, nicotine withdrawal symptoms, and rewarding effects of smoking during a quit attempt. Psychopharmacology (Berl). 2008; 197:371-377.

65. Cahill K, Stead LF, Lancaster T. Nicotine receptor partial agonists for smoking cessation. Cochrane Database Syst Rev. 2008;16: CD006103.

66. Mills EJ, Wu P, Spurden D, et al. Efficacy of pharmacotherapies for short-term smoking abstinance: a systematic review and meta-analysis. Harm Reduct J. 2009;6:25.

67. Wang C, Xiao D, Chan KP, Pothirat C, Garza D, Davies S. Varenicline for smoking cessation: a placebo-controlled, randomized study. Respirology. 2009;14:384-392.

68. Williams KE, Reeves KR, Billing CB Jr, et al. A double-blind study evaluating the long-term safety of varenicline for smoking cessation. Curr Med Res Opin. 2007;23:793-801.

69. Moore TJ, Cohen MR, Furberg CD; Institute for Safe Medication Practices. Strong safety signal seen for new varenicline risks. 2008 May 21. Available from: http://www.ismp.org/docs/vareniclinestudy. asp. Accessed 2008 May 29.

70. Institute for Safe Medication Practices. Quarter Watch (3rd Quarter 2008): Safety concerns with generics, Chantix aggressive behavior, and more. 2009 May 7. Available from: http://www.ismp.org/Newsletters/ acutecare/articles/20090507.asp. Accessed 2010 March 29.

71. US Food and Drug Administration. Safety alerts for human medical products: Chantix (varenicline). 2007 November 20. Available from: http://www.fda.gov/Safety/MedWatch/SafetyInformation/ SafetyAlertsforHumanMedicalProducts/ucm 152098.htm. Accessed 2007 November 23.
72. US Food and Drug Administration. Public health advisory: important information on Chantix (varenicline). May 16, 2008. Available from: http://www.fda.gov/cder/drug/advisory/varenicline.htm. Accessed 2008 May 29.

73. Lyon GJ. Possible varenicline-induced paranoia and irritability in a patient with major depressive disorder, borderline personality disorder, and methamphetamine abuse in remission. J Clin Psychopharmacol. 2008;28:720-721

74. Kintz P, Evans J, Villain M, et al. Smoking cessation with varenicline: a suicidal fatality. J Anal Toxicol. 2009;33:118-120.

75. Kutscher EC, Stanley M, Oehlke K. Chantix-induced mental status changes in a young healthy female. S D Med. 2009;62:193-195.

76. Purvis TL, Mambourg SE, Balvanz TM, et al. Safety and effectiveness of varenicline in a veteran population with a high prevalence of mental illness. Ann Pharmacother. 2009;43:862-867.

77. Kasliwal R, Wilton LV, Shakir SA. Safety and drug utilization profile of varenicline as used in general practice in England: interim results from a prescription-event monitoring study. Drug Saf. 2009;32:499-507.

78. US Dept of Transportation, Federal Motor Carrier Safety Administration. Statement from administrator. 2008 May 23. Available from: http://www. fmcsa.dot.gov/statement-5-23-08.htm. Accessed 2008 May 28.

79. Federal Aviation Administration. Anti-smoking medicine Chantix banned. 2008 May 23. Available from: http:/www.faa.gov/news/ updates/index.cfm?newsld=56363. Accessed 2008 May 28.
Drug, Healthcare and Patient Safety

\section{Publish your work in this journal}

Drug, Healthcare and Patient Safety is an international, peer-reviewed open-access journal exploring patient safety issues in the healthcare continuum from diagnostic and screening interventions through to treatment, drug therapy and surgery. The journal is characterized by the rapid reporting of reviews, original research, clinical, epidemiological and

\section{Dovepress}

post-marketing surveillance studies, risk management, health literacy and educational programs across all areas of healthcare delivery. The manuscript management system is completely online and includes a very quick and fair peer-review system. Visit http://www.dovepress.com/ testimonials.php to read real quotes from published authors. 